\title{
Editorial
}

\section{Aquitard Fluids and Gases}

\author{
Ian D. Clark $\left(D,{ }^{1}\right.$ M. Jim Hendry $\left(\mathbb{D},{ }^{2}\right.$ Jean-Michel Matray, ${ }^{3}$ \\ Douglas Kip Solomon, ${ }^{4}$ and H. Niklaus Waber $\mathbb{1}^{5}$ \\ ${ }^{1}$ University of Ottawa, Ottawa, ON, Canada \\ ${ }^{2}$ University of Saskatchewan, Saskatoon, SK, Canada \\ ${ }^{3}$ Institut de Radioprotection et de Sûreté Nucléaire (IRSN), Fontenay-aux-Roses, France \\ ${ }^{4}$ University of Utah, Salt Lake City, UT, USA \\ ${ }^{5}$ University of Bern, Bern, Switzerland
}

Correspondence should be addressed to Ian D. Clark; idclark@uottawa.ca

Received 7 March 2018; Accepted 7 March 2018; Published 3 July 2018

Copyright (C) 2018 Ian D. Clark et al. This is an open access article distributed under the Creative Commons Attribution License, which permits unrestricted use, distribution, and reproduction in any medium, provided the original work is properly cited.

Porewaters in aquitards have origins and geological histories ranging from freshwaters emplaced with clay sediments [1], primary diagenetic fluids in marine systems [2, 3], and systems mixed over geological time [4]. Determining their origin and fate and the transport of dissolved constituents in these porewaters is complex. Research on fluids and gases in aquitards has increased over the past two decades, largely driven by the need for nuclear agencies to find suitable sites for deep geological repositories to isolate nuclear waste. Understanding the characteristics of aquitards as barriers to contaminant transport to shallow aquifers is also key to the development of unconventional oil and gas reserves. These regulatory and economic drivers have amplified industrial support for research on aquitard fluids and accelerated the rate of peer-reviewed publications from less than one per year just three decades ago to more than 15 per year today, highlighting advances in methods for porewater analysis (cf. [5]), pore gases analysis [6, 7], and the development of diffusion parameters [8]. This special issue presents new research that describes methods to characterize porewaters and gases in aquitards, the diffusive characteristics of aquitards, and methods to characterize aquitard porewaters and solute profiles to simulate diffusive transport in these critical barriers.

Analyzing porewater composition is a critical first step in characterizing aquitard fluids and remains a challenge where the essential condition of low-permeability complicates the task. Two papers address this issue. M. Celejewski et al. present a new method using absorption by capillary tension to extract porewaters onto cellulosic paper that is sealed between two faces of a split core sample. Their findings highlight the process of anion exclusion in the mobile fraction of porewaters in the Ordovician shales of the Michigan Basin where hydraulic conductivities are as low as $10^{-14} \mathrm{~m} / \mathrm{s}$. U. Mäder uses artificial porewater to displace in an advective manner the mobile water fraction of the natural porewater under confining pressure from aquitard rocks with similarly low hydraulic conductivities. The advantage of this technique lies in the fact that the first few $\mathrm{mL}$ of displaced porewater are unaffected by induced reactions with the rock or atmosphere. This allows complete chemical characterization of the porewater including $\mathrm{pH}$ and redox. Like M. Celejewski et al., this method highlights the small difference between $\mathrm{Cl}^{-}$ and $\mathrm{Br}^{-}$transport in systems where anion exclusion becomes important.

In situ porewater pressure is an important feature of aquitard systems, one which reflects the state of openness of the formation to porefluid migration and transport. I. Morales-Arredondo et al. present insights into the origin of the overpressured diagenetic fluids developed in the Cerro Prieto basin of the Salton Sea, relating the geochemistry of these brines to the formation and alteration of mineral phases that preclude dewatering and that maintain overpressured conditions. Fluid-mineral interactions maintaining an overpressured system contrasts with the more mobile fluids of a normal-pressured sediment system presented by Q. Ge et al. 
from the North Jiangsu coastal plain, a region that hosts much younger Pleistocene to Holocene remnant seawater with freshwater inputs. S. D. Normani et al. present a contrasting site that completes this spectrum, where shales and argillaceous limestones in the eastern margin of the Michigan Basin in southern Ontario are underpressured by up to $300 \mathrm{~m}$ below hydrostatic. Their 1D hydromechanically coupled modelling of fully saturated conditions shows the resilience of this system to glacial perturbations during the Pleistocene and suggest that the stable underpressured conditions are likely remnant from post-Mesozoic exhumation.

The diffusion properties of argillaceous sediments are critical to defining transport in aquitard barriers. E. Jacops et al. explore a different parameter-the effect of the size of nonreactive solutes on diffusion parameters. Using Eigenbilzen Sands, Opalinus Clay, Callovo-Oxfordian Clay, and the Boom Clay, they measure and model through-diffusion of gases from $\mathrm{He}$ and $\mathrm{H}_{2}$ to $\mathrm{Xe}$ and ethane. S. Savoye et al. investigate the case of diffusion under partial gas saturation using the Callovo-Oxfordian claystone, comparing marginally conservative $^{22} \mathrm{Na}$ and reactive Cs with HTO. A. Pazdniakou and M. Dymitrowska examine advective free-gas transport in watersaturated clays using a hydraulic-mechanical model and show the importance of localized dilatant pathways in the CallovoOxfordian claystone. All three studies address the important case of gas transport in aquitards.

Case studies remain an important area of research which allow us to apply and assess advanced field-testing methods to aquitard study sites. S. C. Priestley et al. use traditional conservative tracers, $\mathrm{Cl}^{-}$and ${ }^{4} \mathrm{He}$, to constrain vertical transport through the aquitard underlying the Great Artesian Basin in central Australia, showing how these porewater profiles record paleohydrological conditions and impacts of past climates on recharge. K. Nakata et al. detail the challenges in reconstructing porewater ages in a case study where ${ }^{4} \mathrm{He}$ ingrowth and ${ }^{36} \mathrm{Cl}$ decay for over $1 \mathrm{My}$ demonstrate near closed conditions since uplift. A greater focus on redox reactions is presented by C. Lerouge et al. in a case study of the Tégulines Clay in the Eastern Paris Basin where porewater chemistry and mineralogy show a progressive trend towards oxidation in the shallow aquitard.

The breadth of research presented in this special issue demonstrates the considerable interest and significant advances in the study of aquitard fluids and gases. We believe the high-quality of recent contributions to the science of aquitard hydrogeology, including those presented in this special issue, meets the challenge of demonstrating the integrity of aquitard barriers for the protection of freshwater resources.

\author{
Ian D. Clark \\ M. Jim Hendry \\ Jean-Michel Matray \\ Douglas Kip Solomon \\ H. Niklaus Waber
}

of geologic events in a thick aquitard system," Water Resources Research, vol. 35, no. 6, pp. 1751-1760, 1999.

[2] I. D. Clark, T. Al, M. Jensen et al., "Paleozoic-aged brine and authigenic helium preserved in an Ordovician shale aquiclude," Geology, vol. 41, no. 9, pp. 951-954, 2013.

[3] Intera Engineering Ltd, "Descriptive geosphere site model," Intera Engineering Ltd. report for the 104 Nuclear Waste Management Organization NWMO DGR-TR-2011-24, Toronto, Canada, 2011, 105, http://www.nwmo.ca/uploads/DGR\%20PDF/ Licensing/DGSM.pdf.

[4] M. Mazurek and A. de Haller, "Pore-water evolution and solutetransport mechanisms in Opalinus Clay at Mont Terri and Mont Russelin (Canton Jura, Switzerland)," Swiss Journal of Geosciences, vol. 110, no. 1, pp. 129-149, 2017.

[5] F. Bensenouci, J. L. Michelot, J. M. Matray, S. Savoye, M. Massault, and A. Vinsot, "Coupled study of water-stable isotopes and anions in porewater for characterizing aqueous transport through the Mesozoic sedimentary series in the eastern Paris Basin," Marine and Petroleum Geology, vol. 53, pp. 88-101, 2014.

[6] M. J. Hendry, T. G. Kotzer, and D. K. Solomon, "Sources of radiogenic helium in a clay till aquitard and its use to evaluate the timing of geologic events," Geochimica et Cosmochimica Acta, vol. 69, no. 2, pp. 475-483, 2005.

[7] D. Rufer and H. N. Waber, Noble and reactive gas data of porewaters and rocks from the Schlattingen borehole SLA-1, Nagra Arbeitsbericht NAB 15-012, Nagra, Wettingen, Switzerland, 2015.

[8] T. Gimmi, O. X. Leupin, J. Eikenberg et al., "Anisotropic diffusion at the field scale in a 4-year multi-tracer diffusion and retention experiment-I: Insights from the experimental data," Geochimica et Cosmochimica Acta, vol. 125, pp. 373-393, 2014.

\section{References}

[1] M. J. Hendry and L. I. Wassenaar, "Implications of the distribution of $\delta \mathrm{D}$ in pore waters for groundwater flow and the timing 

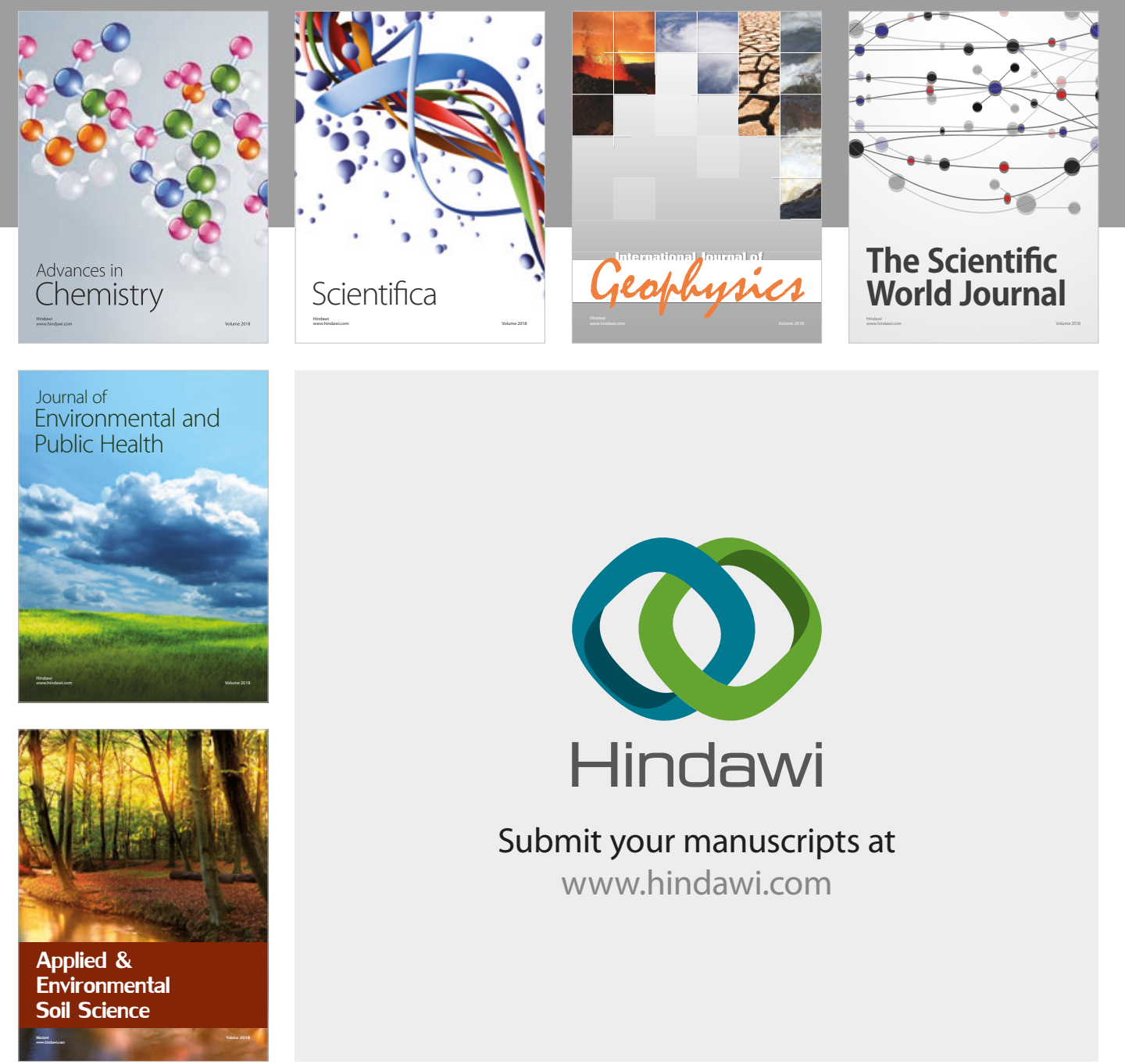

The Scientific

\section{World Journal}
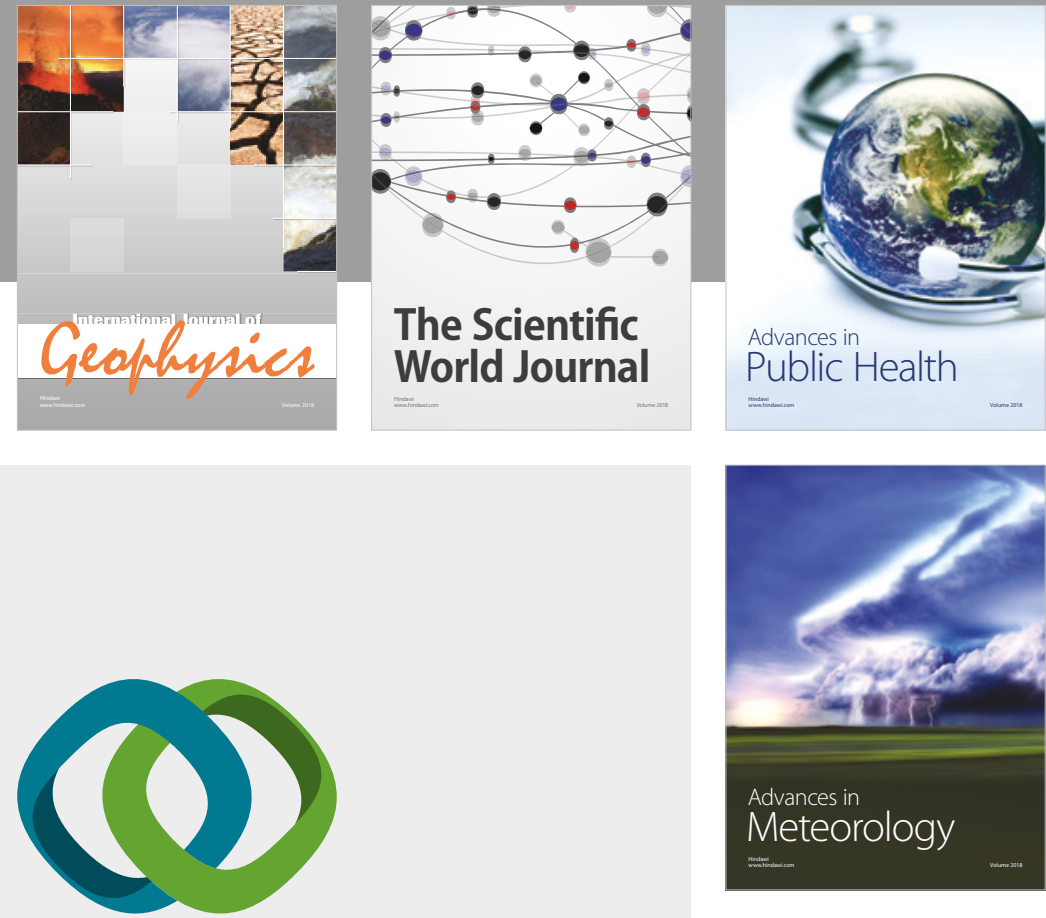

Advan

Public Health

\section{Hindawi}

Submit your manuscripts at

www.hindawi.com
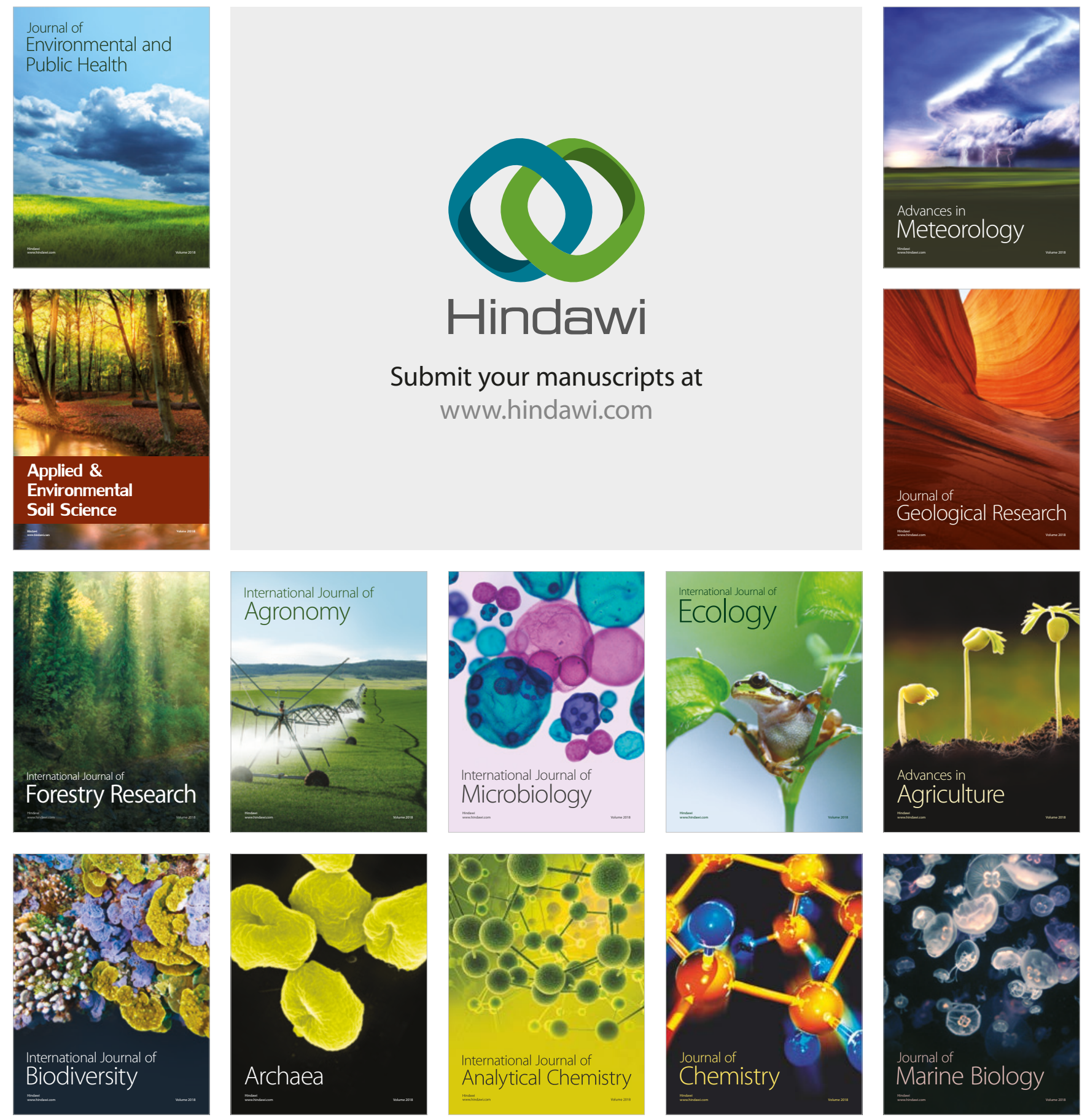